\title{
Microsurgical technique for the bisection of early embryos in the mouse, rabbit and cow
}

\author{
Shyoso OGawa, Kohji MiYake*, Noboru SeIKE** \\ and Hiroshi KanagaWA*** \\ Laboratory of Animal Reproduction, Meiji University, \\ Higashimita-1, Kawasaki 214
}

\begin{abstract}
Summary. The technics developed for suitable bisection of mouse and rabbit early embryos were described: 1) bisection by lateral incision of embryos, applying a sharp glass microblade at the side face, and wedging it in a horizontal direction, 2) bisection by vertical incision, moving down a metallic microneedle (made from Pt-Ir alloy wire, tip point of which is ground electrolytically) vertically to press the mid-part of embryos. These 2 methods were applied to bisection of bovine morulae. Methods of removal and transfer of the demi-embryos from and shell of Z.P. by using a glass microtube which had a slightly bevelled tip point was also discussed.

In total, 25 out of 29 bovine morulae, using both methods, were successfully bisected. In conclusion, both methods are equally useful for the bisection of bovine morulae.

By cultivation of bisected embryos using the medium of HER solution added to $18 \%$ calf serum at $37 \mathrm{C}$, under saturated humidity and $5 \% \mathrm{CO}_{2}$ atmosphere, 22 out of 26 bisectomized demi-embryos in total (time required, about $2.5 \mathrm{~h}$ from collection to the onset of operation) showed the following in vitro development; i.e., 2 out of 2 halved naked embryos cut by a glass microblade, 16 out of 18 naked demi-embryos cut by a Pt-Ir metallic microneedle and 4 out of 6 zona enclosed demi-embryos cut by the metallic needle and transferred successfully into alien Z.P., developed up to late morula stage at $12 \mathrm{~h}$ culture and to early expanding blastocyst stage at $24 \mathrm{~h}$ culture.
\end{abstract}

(Japan. J. Anim. Reprod., 29, 198-208, 1983)

\section{Introduction}

Recently, production of monozygotic twins in mammals by transplantation of bisected early embryos ${ }^{1-8)}$ has become feasible. The required steps in the micrurgic technique for successful dichotomy may be crucial in the determination of twin production.

For several years, we have improved micrurgic techniques ${ }^{7,8)}$ using embryos of

*Shizuoka Prefectural Animal Husbandry Experimental Station, Uchino, Fujinomiya 418-02, **Laboratory of Embryo Transfer, Snow Brand Milk Products Co. Ltd., Bekkai, Hokkaido 086-02, \& ***Department of Veterinary Obstetrics, Faculty of Veterinary Medicine, Hokkaido University, Sapporo 060 . mice, rats and rabbits. Before, practical application of these improved techniques for bisection of the bovine embryos, we compared vertical incision of the embryo by pressing down with a fine metallic needle and the lateral incision of the embryo face with a fine glass microblade. Both methods have been found useful for bisection of the bovine embryo in morula stage.

This paper describes the major steps in techniques which are universally applicable for mouse, rabbit and bovine embryos. In addition, the developmental potential of the embryos examined in vitro after bisection is discussed. 


\section{Experimentals}

Animals and Embryos: DDY strain mice ( 8 to 10 weeks old, weighing from 18 to $23 \mathrm{~g}$ ) and Japanese White rabbits (6 to 15 months old, weighing from 3.6 to $3.8 \mathrm{~kg}$ ) were used for the collection of embryos. They were superovulated by administration of PMSG and hCG according to the methods reported by FOWLER \& EDWARDS ${ }^{9)}$ and ISHIJIMA \& SAKU$\mathrm{MA}^{10)}$ for mice and rabbits, respectively. Immediately after injection of $\mathrm{hCG}$, animals were mated with fertile males of the same species. Morula stage embryos were recovered from the fallopian tubes in rabbits and from the uterine horns in mice, by flushing them with culture media at 60 to $63 \mathrm{~h}$ and 74 to $78 \mathrm{~h}$ after the injection of hCG, respectively.

Holstein cows reared at Shizuoka Prefectural Animal Husbandry Experimental Station (SPAHES) and at Bekkai-town and its environs, Hokkaido, were injected with $4000 \mathrm{IU}$ of PMSG on the 10th to 14th day of the estrous cycle. Two days later the animals were injected with $30 \mathrm{mg}$ of $\mathrm{PGF}_{2 \alpha}$, then artificially inseminated in the evening of first estrous day and in the following day. Six to seven days after insemination, embryos at morula stage were collected by in vivo flushing of the uterus. Bovine embryos collected were transferred to Dulbecco's phosphate buffer solution $(\mathrm{PBS})^{11)}$ containing 15\% calf serum. The embryos were added to $0.5 \mathrm{ml}$ of the solution and placed in a stoppered plastic straw tube (commercially used for artificial insemination of cattle). Transportation time to the laboratory required was about $2.5 \mathrm{~h}$ from SPAHES and about $12 \mathrm{~h}$ from Bekkai via land and air. The straw tubes were kept in the inner pocket of a transporter during transport.

Microsurgical Techniques: The embryos were transferred in the central part of a plastic petri dish $(90 \mathrm{~mm}$ in diameter and 15 $\mathrm{mm}$ in depth) with a small amount of culture medium, covered with 15 to $20 \mathrm{ml}$ of liquid paraffin. The dish was placed on the fixed stage of an inverted phase contrast microscope for micrurgy.

1) Lateral incision of an embryo with a fine glass blade (or fine metallic blade).

For this type of micrurgy, a fine glass blade was prepared from a strip of $3 \mathrm{~mm}$ width cover glass with one edge polished with a micropipet grinder (Narishige Scientific Instr. Lab., EG-3) (Fig. 1a). The glass blade was fixed on a shaft with glue and connected to the micromanipulator. In micromanipulation, an embryo was fixed by suction from one side and an edge of the blade was placed on the opposite lateral side. Then, the embryo was divided into halves (Fig. 1, 1-4). Examples of this method applied to rabbit morulae are shown in micrographs of Fig. 2.

In this case, the blade was pushed onward through the zona pellucida (Z.P.) to the middle part of the embryo (Fig. 2a), separating the embryo into two masses of compact blastomeres (Figs. 2b \& c). By cutting deeper, both Z.P. and embryo were concurrently separated in toto (Fig. 2c). After removal of the blade, two masses of blastomeres remained in partially cut Z.P. (Fig. 2d).

This cutting method applied to the rabbit morulae, of which mucin layers were removed previously by the pronase treatment ${ }^{7)}$, has given a good result as will be discussed later.

During this study, we became interested in the recent report of WILliams et al. ${ }^{5)}$ who had succeeded in lateral bisection of bovine morula embryos, using a strip-sharpened metallic blade with a shaft connected to the micromanipulator. 


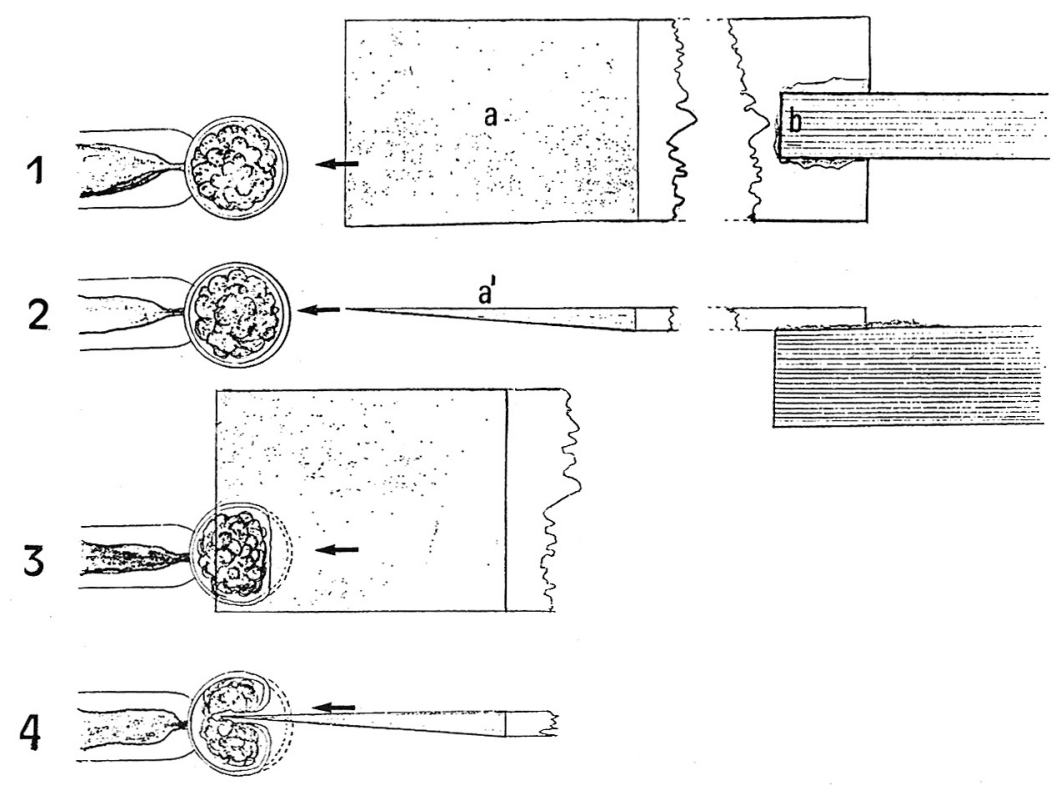

Fig. 1. Diagrammatic illustration of bisectomy of early embryo by a fine glass blade. a: part of a glass blade, b: a blade glued to a shaft, $a^{\prime}$; top view of a blade edge.

(1) Side view of an embryo held by suction and a glass blade glued to a shaft (arrow showing the sliding direction of blade). (2) Top view of the same above. (3) Side view showing the blade cut deeply into the embryo. (4) Top view corresponding to (3).
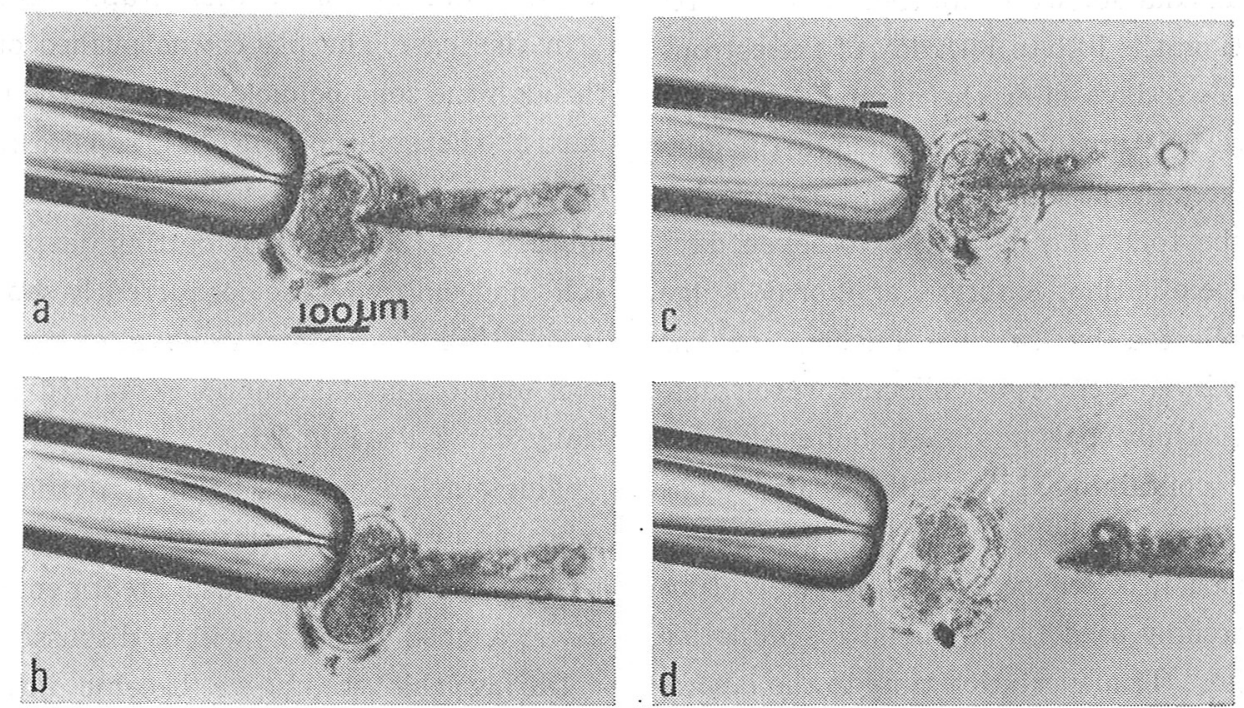

Fig. 2. Bisection of rabbit morula with a glass blade by pushing it on the lateral direction.

a: Application of a blade to the side face of a morula, $b$ : The blade is pushed onwards through Z.P. so as to bisect the embryonic cell mass, c: Z.P. becomes intolerable to the pressure, the Z.P. and embryo being cut concurrently, d: After removal of the blade, 2 isolated demi-embryos are seen inside of Z.P., a-d: all in the same magnification. 
To determine whether the metal blade is also useful for the bisection of early stage embryos, in contrast to the glass microblade, we prepared a metallic cutter with ultra-sharp edge by snapping off a blade to strip-sharped $(2 \times 9 \mathrm{~mm})$. The edge was electrolytically ground (with equivalent mixture of $50 \% \mathrm{NaCN}$ and 30\% NaOH, AC 3-5v) (Fig. 3a). The blade was glued to a shaft connected to the micromanipulator and used for bisection of the rabbit embryos (Figs. $3 b \& c$ ).

2) Cutting process of embryos by the metallic microneedle.

Bovine embryos at morula stage were transferred to the Dulbecco's PBS containing

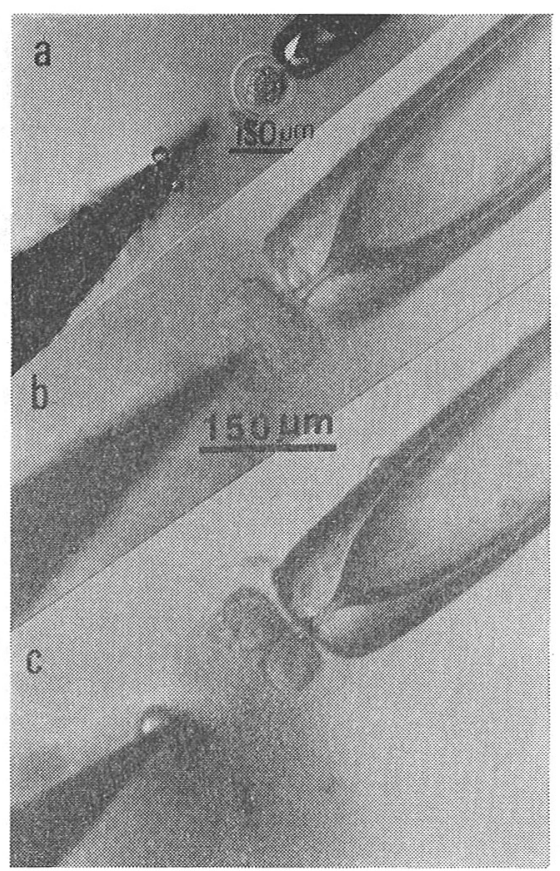

Fig. 3. Bisection of rabbit morula by a metallic microblade pushing on the lateral direction. a: Top of the metallic blade approaching in lateral direction to the embryo fixed by a holding pipet, b: Application and pushing the blade to side face of the embryo, c: After the withdrawal of the blade, two demi-embryos are seen in contact inside of Z.P., b \& c: at the same magnification. a
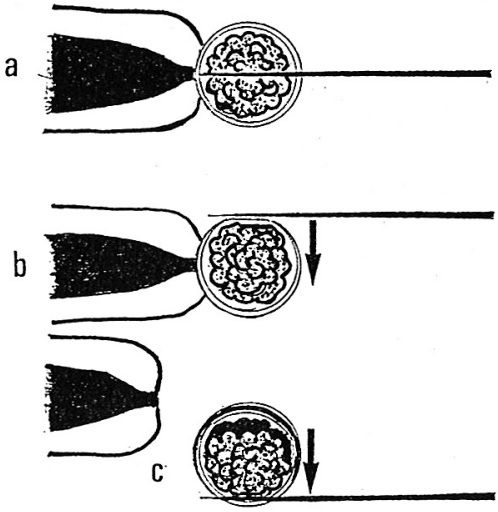

d

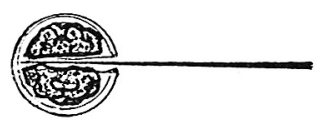

Fig. 4. Diagrammatic illustration of bisectomy of early embryo using a fine metallic microneedle.

a: Top view; just applied the needle tip on the top of the embryo, b: Side view; moving the needle down to press and immobilize the embryo in the direction of arrow, c: Side view; the needle is put down to cut the embryo, until it touches to the basement of a dish. A holding pipet is removed from the field of vision, d: Top view, top view of c.

5000-6000 Tyrosin units/m $l$ of pronase (Kaken Pharm. Co.), kept for 1.5 to $3 \mathrm{~min}$ at room temperature, and then washed 3 times with culture media to soften the Z.P. In general, the zonae of the bovine embryos are considerably tough when compared with those of the mouse and the rabbit. Therefore, the metallic microneedle of the wire $(100 \mu \mathrm{m}$ in diameter) of Pt-Ir alloy consisting of $70 \%$ of platinum and $30 \%$ of iridium was ground at its point by electrolytic grinding as described. The needle was glued to a stainless steel pipe (inside diameter; $100 \mu \mathrm{m}$ ) connected to the micromanipulator. The point of the needle was applied on the top of an embryo fixed by suction with a holding pipet (Figs. $4 \mathrm{a} \& \mathrm{~b}$ ). 

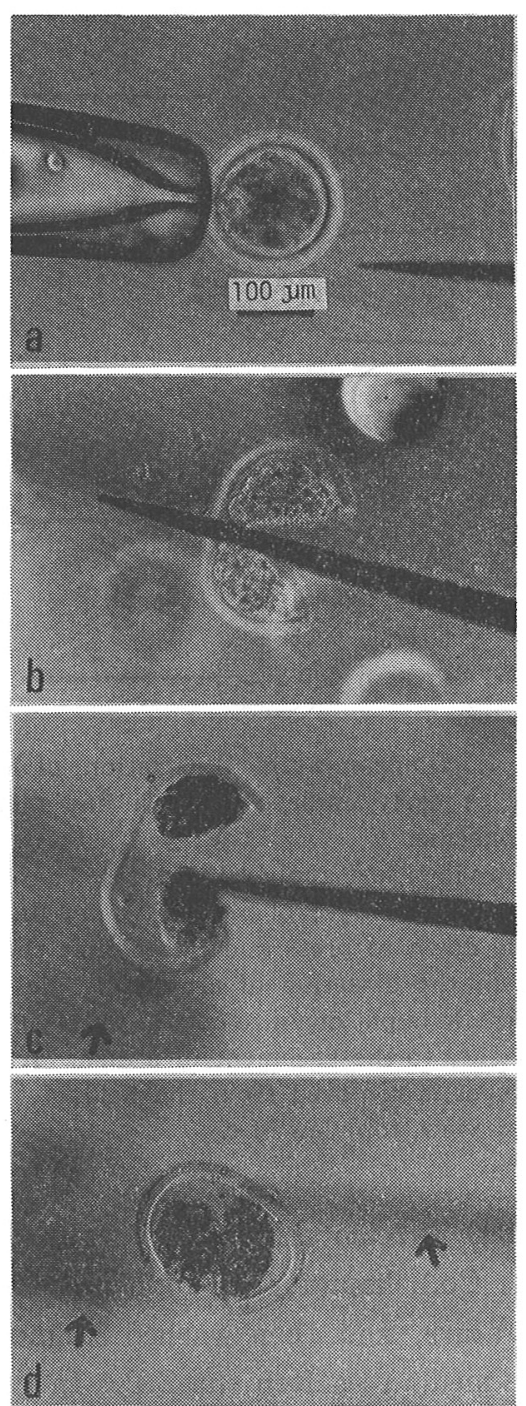

Fig. 5. Bisection of bovine morula by a metallic microneedle (top view).

a: Left; embryo is immobilized by suction with a holding pipet. Right; the tip of the microneedle, b: The tip of the microneedle touching the basement of a dish. The embryo is divided into 2 demi-embryos, c: Wider space between 2 demi-embryos is made by twisting the microneedle, Arrow; a shadow showing the removal of holding pipet from the field of vision, d: On immediate withdrawal of the microneedle, Two demi-embryos in contact within Z.P. can be seen, Left arrow; shadow of the holding pipet, Right arrow; shadow of the microneedle, a-d; all in the same magnification.
Then, the needle is moved down pressing the mid-part of embryo toward the basement of a dish (Figs. $4 c \& d$ ).

Coincidentally, with attachment of the needle to the basement of the dish, the embryo can be cut completly together with Z.P. by rubbing the point of needle against the dish surface. The bisection is attainable solely by the vertical operation of the needle. When cutting the embryo by the needle at $2 / 3$ point of the embryo's diameter, it resulted in bisected embryos with a baggy Z.P. Fig. 5 shows bovine morulae applied this procedure. Still, when narrow bridges remain between 2 blastomeres, it can be divided by using a

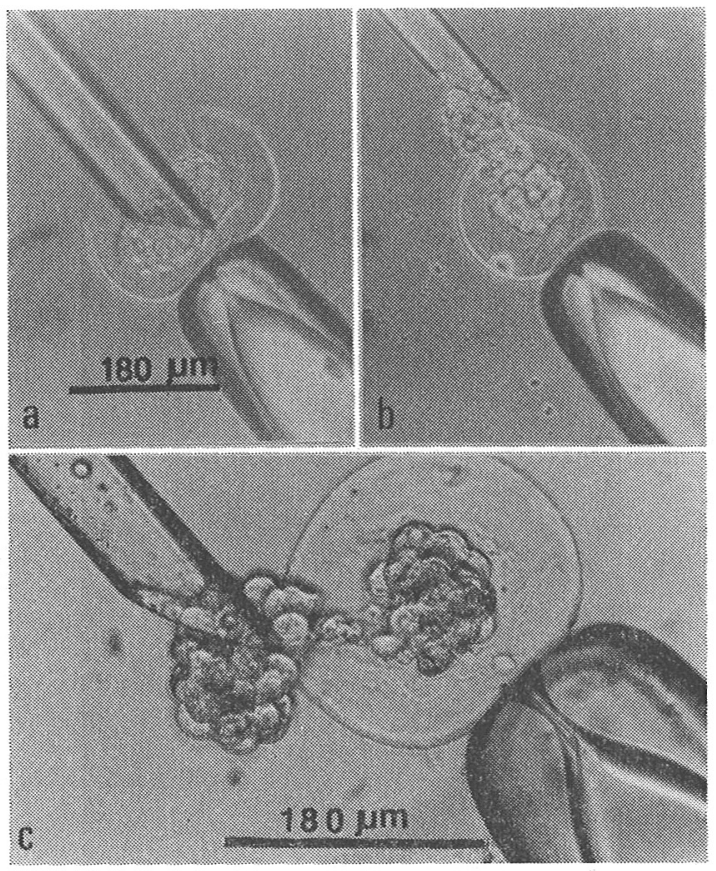

Fig. 6. Procedure for the removal of bisected rabbit embryos from their Z.P.

a: The sharp point of the micromanipulative pipet (the tip was bevelled to a $25-30^{\circ}$ angle) is inserted into incised part of Z.P., b: One of the 2 demi-embryos is suctioned to an oblique opening of the pipet, c: The demi-embryo is then removed from a cracked space of Z.P. $\mathrm{a} \& \mathrm{~b}$; in the same magnification. 
needle (Fig. 5b) or other operation pipet.

It is advisable that, in pressing down the embryo from above with a microneedle, the operator pulls down the needle as quickly as possible; continuous and intermittent pressing may produce damage to the embryonic parenchyma.

3) Procedures for the removal of bisected embryos from the shell of Z.P. and for the embryo transfer into other vacant Z.P.

As shown in Fig. 6 the demi-embryos were removed through a cracked space of Z.P. by suction with a micromanipulative pipet, the tip of which was beveled to a 25$30^{\circ}$ angle by a pipet grinder. The specimens were then transferred into alien empty zonae by pushing out from the pipet passing through the open space of Z.P.

A stock of the alien zonae was previously prepared from the oocytes of the ovaries of rabbits and sows as follows; the oocytes obtained by aspiration of follicles were immediately subjected to freezing $(-30 \mathrm{C})$ and thawing $(37 \mathrm{C})$. By this treatment, their cumulus cells which tightly attached to the zonae easily dispersed into surrounding medium. The naked ovum was cracked by applying the vertical incision method using the metallic needle to $1 / 2-2 / 3$ point of the ovum diameter. As a result of the operation, a

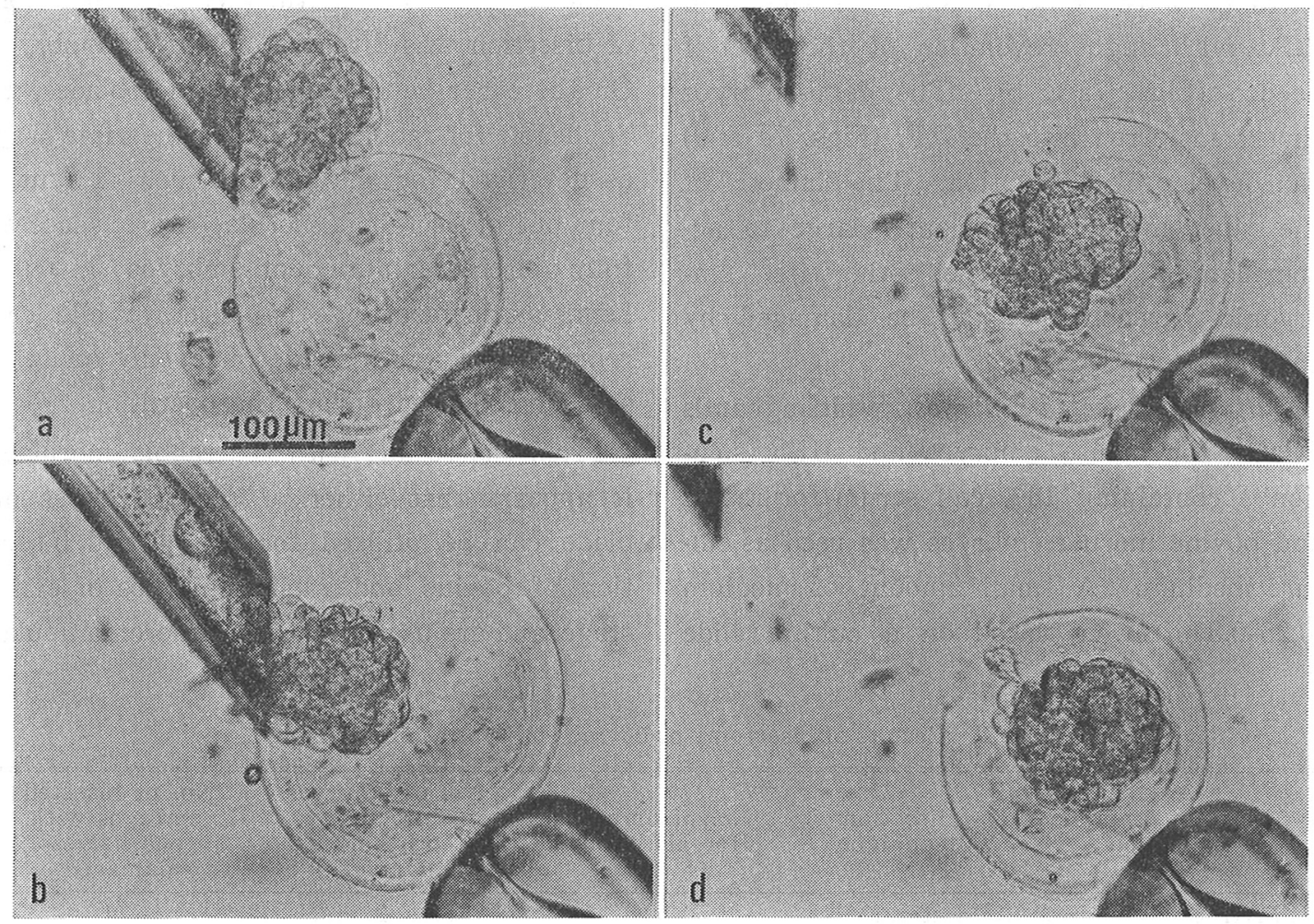

Fig. 7. Procedure for the rabbit demi-embryo replacement into the alien empty Z.P. a: Immobilization of the demi-embryo by the micromanipulative pipet at its oblique opening, b: Introducing the demi-embryo into inside of alien Z.P. passing through its cracked space, c: Placement of the demi-embryo into the cracked space, d: Completion of the replacement of the demi-embryo into the alien empty Z.P. a-n; all in the same magnification. 
cracked ovum with a baggy Z.P. was obtained. Then the blastomeric mass was gently pushed out of the zonary antrum with the micromanipulative needle. These baggy and empty zonae were stored at $-25 \mathrm{C}$ in Dulbecco's PBS $^{11)}$ containing 15\% calf serum, and the frozen-thawed empty zonae from rabbits were used as the alien Z.P. for receiving the rabbit demi-embryos, while those from sows were used for receiving the bovine demi-embryos, respectively.

The isolated demi-embryo was fixed very gently by suction of micromanipulative pipet at its oblique opening (Fig. 7). Then the sharp point of the pipet was pushed into the entrance of the cracked space of the alien Z.P., with slight revolution of the pipet if needed (Figs. 7a \& b). The demi-embryos thus transferred into the Z.P. (Figs. 7c \& d) can develop by cultivation. The diameter of the pipet must be sufficiently large to accomodate a demi-embryo, otherwise, embryonic parenchyma may be damaged by compression.

Culture of Bisected Embryos. Whittingham's $\mathrm{SCM}^{12)}$ for mouse embryos and HER solution $^{13)}$ containing $18 \%$ calf serum for rabbit and bovine morula embryos was used as culture medium. A small amount of medium $(0.25-0.3 \mathrm{~m} l)$ was placed on a culture slide
(Lab-Tek made, No. 4804), covered with 1 to $2 \mathrm{~m} l$ of liquid paraffin. The conditions are follows: temperature, $37 \mathrm{C}$; atmosphere, $5 \%$ $\mathrm{CO}_{2}$; humidity, saturated; time, 12 or $24 \mathrm{~h}$; microscopic examination, every $6 \mathrm{~h}$.

\section{Results and Discussion}

Lateral incision of embryos by a glass microblade has successfully been carried out in 18 mice embryos and 12 rabbit embryos, respectively. Similarly, 4 bovine morulae were bisected, including one demi-embryo injured to destroy (Table 1).

In the operation of bovine embryos, the time required for bisection from setting the blade to embryo's lateral face to completion of bisection was 2 to 4 minutes per embryo. On the other hand, a metallic microblade was applicable for rabbit morulae in the same way as described for the glass blade. Twentyfour out of 28 rabbit morulae were successfully bisected into demi-embryos in the hemispheric form of equal size. While the remaining 4 were divided unevenly and the smaller collapsed during the operation.

From the results with the rabbit morulae, it appears that either of these 2 types of blade can be utilized for the lateral bisection of bovine and rabbit embryos of early stage, and are useful for other micromanipula-

Table 1. Results of bisectomy of bovine embryos at morula stage

\begin{tabular}{|c|c|c|c|c|}
\hline $\begin{array}{l}\text { Place of embryo } \\
\text { collection }\end{array}$ & $\begin{array}{l}\text { Bisection } \\
\text { technique }\end{array}$ & $\begin{array}{l}\text { No. of embryos } \\
\text { for bisectomy }\end{array}$ & $\begin{array}{c}\text { No. of embryos } \\
\text { bisected } \\
\text { (both halves } \\
\text { undamaged) }\end{array}$ & $\begin{array}{l}\text { No. of bisected } \\
\text { embryos with } \\
\text { one halves } \\
\text { damaged }\end{array}$ \\
\hline SPAHES* & Lateral & 2 & 2 & 0 \\
\hline Bekkai** (Hokkaido) & incision & 2 & 1 & 1 \\
\hline SPAHES* & Vertical & 14 & 13 & 1 \\
\hline Bekkai** (Hokkaido) & incision & 11 & 9 & 2 \\
\hline
\end{tabular}

* Shizuoka Prefectural Animal Husbandry Experimental Station.

** Bekkai-town and its environs, Hokkaido. 
tion requiring an ultra-sharp edge. Since droplets of liquid paraffin tend to adhere to the surface of microblade, cautions must be taken, to avoid this possibility, or the surface or edge of the glass or metallic blade becomes indistinct.

Results of the vertical incision of bovine morulae by pressing the metallic microneedle are shown in Table 1 . All of 25 morulae pretreated with pronase could be bisected by the manipulation of microneedle, except 3 in which demi-embryos were damaged by compression during the operation. It appeared that time required for embryo transportation has no deleterious effect on the results.

Judging from the results of bisection and from the observations of developmental potential of demi-embryos, these two techniques, lateral and vertical incisions employed here, seem to be equally useful for bisection of bovine early embryos.

The bisected rabbit and bovine embryos were freed from the parent Z.P., using a glass pipet with bevelled tip, and transplanted into empty alien Z.P. When parts of the demiembryos or the Z.P. are connected to each other with narrow bridges, the demi-embryos can be removed through a cracked space of Z.P. by suction with a micromanipulative pipet (Fig. 6). In this case, control of suction, even under the micromanipulation, is difficult. If the suction is too strong, there is a great risk to damage the embryo mainly due to compression. In fact, as shown in Table 2, 2 out of 5 bovine and 3 out of 8 rabbit demiembryos failed to escape from their parent Z.P., resulting in about $60 \%$ success of the embryonic extraction, while all of the 12 embryos including 5 rabbit demis could be replaced into the alien Z.P.

In order to avoid the risk mentioned above, it may be advisable that the zona free demiembryos must be prepared by dichotomy, cutting completely the bridges with Z.P. for embryonic replacement into the alien Z.P. Thus, the technique for the embryonic replacement may be simplified and the operation time shortened for embryonic extraction. In fact, all 4 bovine demi-embryos of zona free, which were prepared by cutting off the bridges to zona, could be introduced successfully into the empty zonae. Although our data is limited to only 4 specimens, application of this procedure would be a good choice in handling zona encased demi-embryos. Five to 13 minutes were required for the removal operation and 3 to 7 minutes for the transfer operation per embryo. The difficulty in this operation depends on the size of the cracked space of Z.P. The smaller incision of Z.P. leads to

Table 2. Results of micromanipulation in the removal and transfer of demi-embryos from the original to the empty alien Z.P.

\begin{tabular}{clccc}
\hline $\begin{array}{c}\text { Procedure in } \\
\text { micrurgy }\end{array}$ & Species & $\begin{array}{c}\text { No. of } \\
\text { original } \\
\text { embryos }\end{array}$ & $\begin{array}{c}\text { No. of } \\
\text { demi-embryos } \\
\text { produced } \\
\text { by }\end{array}$ & $\begin{array}{c}\text { No. of } \\
\text { demi-embryos } \\
\text { encased into } \\
\text { Zlien } \\
\text { successfully }\end{array}$ \\
\hline $\begin{array}{c}\text { Successful removal of } \\
\text { demi-embryos from } \\
\text { shell of Z.P. }\end{array}$ & $\begin{array}{l}\text { Rabbit } \\
\text { Cow }\end{array}$ & 8 & 5 & 5 \\
\hline $\begin{array}{c}\text { Complete bisection of } \\
\text { embryos together } \\
\text { with Z.P. }\end{array}$ & Cow & 5 & 3 & 3 \\
\hline
\end{tabular}


Table 3. In vitro Development of the bisected bovine embryos (Morula stage)

\begin{tabular}{|c|c|c|c|c|}
\hline $\begin{array}{l}\text { Place of embryo } \\
\text { collection }\end{array}$ & $\begin{array}{l}\text { Bisection } \\
\text { technique }\end{array}$ & $\begin{array}{c}\text { Contour of } \\
\text { demi-embryos }\end{array}$ & $\begin{array}{l}\text { No. of demi- } \\
\text { embryos cultured }\end{array}$ & $\begin{array}{l}\text { No. of demi- } \\
\text { embryos developed }\end{array}$ \\
\hline \multirow{3}{*}{ SPAHES* } & $\begin{array}{l}\text { Lateral incision } \\
\text { with glassblade }\end{array}$ & Z.P. Free & 2 & 2 \\
\hline & \multirow{2}{*}{$\begin{array}{l}\text { Vertical incision } \\
\text { with metallic } \\
\text { needle }\end{array}$} & Z.P. Free & 18 & 16 \\
\hline & & Encased in Z.P. & 6 & 4 \\
\hline \multirow{4}{*}{ Bekkai** (Hokkaido) } & \multirow{2}{*}{$\begin{array}{l}\text { Lateral incision } \\
\text { with glassblade }\end{array}$} & Z.P. Free & 2 & 1 \\
\hline & & Encased in Z.P. & 1 & 1 \\
\hline & \multirow{2}{*}{$\begin{array}{l}\text { Vertical incision } \\
\text { with metallic } \\
\text { needle }\end{array}$} & Z.P. Free & 16 & 7 \\
\hline & & Encased in Z.P. & 4 & 2 \\
\hline
\end{tabular}

* Bekkai-town and its environs in Hokkaido.

** Shizuoka Prefectural Animal Husbandry Experimental Station.

Z.P.: Zona Pellucida.
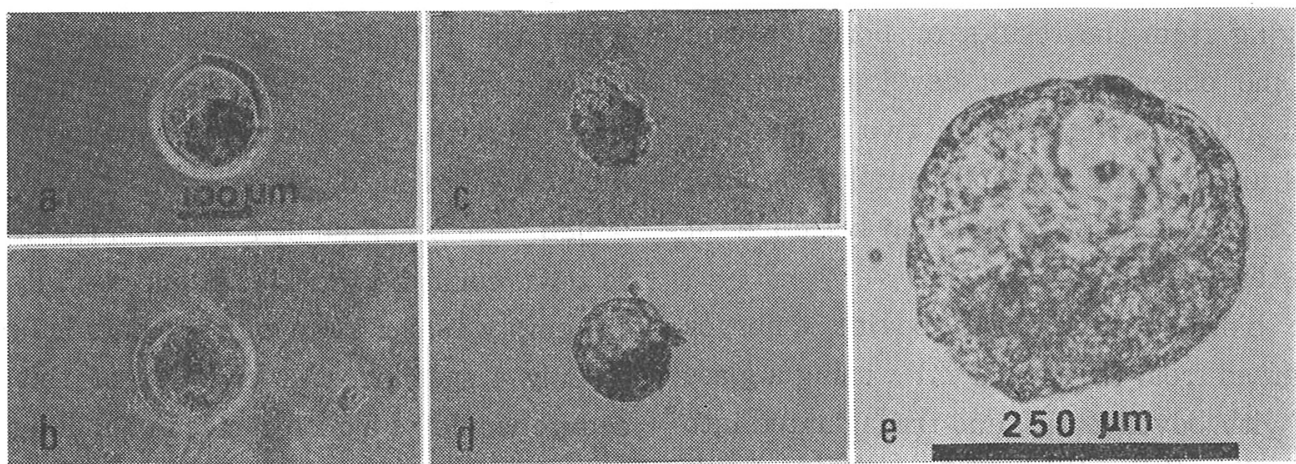

Fig. 8. In vitro development of the bovine embryos bisected at morula stage.

a: Zona encased demi-embryo, $6 \mathrm{~h}$ culture, b: Early blastocyst obtained at $24 \mathrm{~h}$ culture with the zona encased demi-embryo (a), c: Late morula stage of zona freed demi-embryo, $6 \mathrm{~h}$ culture, d: Expanding blastocyst, $24 \mathrm{~h}$ culture in zona free, e: Blastocyst in Z.P. free, prior to full expansion, $24 \mathrm{~h}$ culture, a-d; same magnification.

more difficulty in the operation, and to retardation of the operation time.

Table 3 shows, the summarized results of culture experiments of bisected bovine embryos for 12 to $24 \mathrm{~h}$. When a glass microblade was used, 2 pairs of bisected zona free embryos transplanted from each collection place developed by culture, except one demi-embryo from Bekkai. The bisected embryos obtained by a metallic microneedle also showed the developmental ability, both in the zona free and in the encased alien Z.P. states.
In total, 33 out of 49 halved embryos developed by culture; i.e., 4 out of 5 halves obtained by lateral bisection with the glass blade and, 29 out of 44 halves obtained by vertical bisection with the metallic needle, developed into late morula or early blastocyst stages by $12 \mathrm{~h}$ culture and early blastocyst or early expanding blastocyst stages by $24 \mathrm{~h}$ culture.

With regard to developmental potential of the halved bovine embryos, a distinct difference is found between embryos obtained 
1983 年 12 月

from SPAHES and embryos from Bekkai; 22 out of 26 embryo (85\%) from SPAHES cleaved by culture, while under the same condition 11 of 23 embryos (48\%) from Bekkai cleaved. Such a difference is likely due to the time span between the collection and micrurgy.

Figs. 8a-e demonstrate the typical figures of the late morula in compact form and the expanding blastocyst, both of them derived from the zona encased or the zona free demiembryos produced by the bisection of bovine embryos.

One of the important methods for production of monozygotic twins from one animal embryo by micrurgy is the encasing of bisected demi-embryos into alien Z.P. before transplantation $^{2-6)}$. The presence of the Z.P. may be essential for future embryo development. In the present study, however, we confirmed that the halved bovine embryos of Z.P. free, derived from bisection of morula stage, could develop to expanding blastocyst stage during culture.

Whether these expanding blastocysts of zona free are capable of implanting and growing when transferred into the recipient's uteri of not remains to be clarified.
家畜繁殖誌 29 巻 4 号

Acknowledgments. We are grateful to Prof. Masami YAMANE, Dept. Mechanical Engineering, Waseda University, for supplying the metallic microblade. This work was supported by a Grantin-Aid (No. 56560292) for the Scientific Research from the Ministry of Education, Science and Culture of Japan.

\section{References}

1) Moustafa, L. A. \& J. Hahn: Dtsh. Tierärztl. Wsch., 85, 242, 1978.

2) Willadsen, S. M.: Nature, 277, 298, 1979.

3) Willadsen, S. M., H. Lehen-Jensen, C. B. FEHILLY \& R. NEWCOMB: Theriogenology, 15, 23, 1981.

4) Ozil, J. P., Y. HeYman \& J. P. Renard: Vet. Rec., 110, 126, 1982.

5) Williams, T. J., R. P. Elsden \& G. E. Seidel, JR.: Theriogenology, 17, 114 (Abstr.), 1982.

6) LAMBETH, V. A., C. R. LOONEY, S. A. VOELKEL, D. A. JACKSON, K. G. HILL \& R.A. GODEK: Theriogenology, 20, 85, 1983.

7) Nagashima, H. \& S. Ogawa: Jpn. J. Anim. Reprod., 27, 12, 1981.

8) Nagashima, H., H. Fujikura \& S. Ogawa: Jpn. J. Anim. Reprod., 28, 20, 1982.

9) Fowler, R.E.\& R.G.EDwARDS: J.Endocrinol., 15, 374, 1957.

10) Ishijima, Y. \& Y. Sakuma: Jpn. J. Anim. Reprod., 12, 133, 1967.

11) Dulbecco, R. \& M. Vogt: J. Exp. Med., 99, 167, 1954.

12) Whittingham, D. G.: J. Reprod. Fert., Suppl., 14, 7, 1971.

13) Ogawa, S., K. SatoH \& H. Hashimoto: Nature, 233, 422, 1971.

(Received July 16, 1983) 


\title{
マウス, 家鬼およびウシの初期発生肧に対する切断分離 のための顕微操作法について
}

\author{
尾川昭三・三宅晄次 ${ }^{*} \cdot$ 清家 昇 ${ }^{* *} \cdot$ 金川弘司*** \\ (明治大学家畜繁殖学研究室 *静岡県畜産試験場乳牛部 $* *$ 雪印乳業株式会社 \\ 北海道別海工場胚移植研究室 $* * *$ 北海道大学獣医学部臨床繁殖学講座)
}

\begin{abstract}
マウスおよび家鬼の初期胚を 2 等分断する顕微操作法 として最近筆者らが開発した次の 2 方法すなわち 1) 胚 の側面に鋭利なガラス微細刃を当てて水平方向に切込 み, 胚を 2 等分断する方法, 2) 金属製微細針 $(\mathrm{Pt}-\mathrm{Ir}$ 線 を電解研磨して作製）を㗏上方から押さえつけるよらに して下方に降し, 泼を 2 等分断する方法の概略を記述し た。これら 2 方法を牛桑実胚の 2 等分断手術にも適用し た。先端を研磨して浅く角度をつけたガラス微細管を用 い, 得られた切断 $1 / 2$ 肧の透明帯外への取出し,および 空透明帯への移植操作を施した。
\end{abstract}

この切断の 2 方法を牛胚へ適用し, 総胚数 29 個のら
ち 25 例で切断分離が成功し, 本法は牛桑実胚の切断分 離にも有効であると判断された。得られた分離 $1 / 2$ 泼の 培養（子牛血清 $18 \%$ を加光た HER 液 ${ }^{13)}$ を使用, $37^{\circ} \mathrm{C}$, 湿度飽和, $3 \% \mathrm{CO}_{2}$ 条件下) の結果, 総数 26 個の切断分 離 $1 / 2$ (胚採取後手術に供するまでの所要時間が約 2.5 時間以内のもの) のらち 22 例が発達した。ガラス微細 刃による切断 $1 / 2$ 胚 (裸出胚) 2 例中 2 例, Pt-Ir 針に よる切断 $1 / 2$ 泼 (裸出胚) 18 例中 16 例, また Pt-Ir 針 による切断分離後に空透明帯へ移植し 6 例中 4 例が, 培 養 12 時間で後期桑実胚に，また 24 時間で初期胚盤胞 あるいは膨化開始肧盤胞期に発達した。 